\title{
Student Learning Outcomes Assessment and LIS Program Presentations
}

\author{
Rachel Applegate
}

\begin{abstract}
American Library Association (ALA) standards for the accreditation of library schools emphasize the assessment of student learning outcomes; this is part of a broader accountability movement in higher education. This study reviews accreditors' statements on program assessment, past methods of evaluating library schools, and general definitions of measures of student learning. It then examines fifteen publicly-available "program presentations," self-study documents prepared for ALA-Committee on Accreditation visits and review, for descriptions of direct or indirect measures of student learning outcomes and their use for program-level assessment and improvement. Only seven of the fifteen presentations describe the use of "direct" measures of student learning. Further research on program-level use of outcomes measurement would strengthen the profession and address external pressures for concrete accountability.
\end{abstract}

\section{Introduction}

As educational programs housed in institutions of higher education, library science programs are subject to a growing "culture of assessment" that has gained strength in recent years. There are increasing demands from state and national legislators for documentation of student learning ${ }^{1}$, and accrediting agencies, both regional (general institutional) and professional, have responded.

The 1992 American Library Association Committee on Accreditation (COA) Standards for Accreditation of Master's programs in Library and Information Studies ${ }^{2}$ incorporate specific references to the importance of assessment at several levels. The standard for faculty (III) requires that faculty "demonstrate skill in academic planning and evaluation." Two other standards are even more direct and explicit:

\section{Curriculum}

The curriculum is continually reviewed and receptive to innovation; its evaluation is used for ongoing appraisal, to make improvements, and to plan for the future. Evaluation of the curriculum includes assessment of students' achievements and their subsequent accomplishments. 


\section{About the Author}

Rachel Applegate is an assistant professor, School of Library and Information Science, Indiana University, Indianapolis (rapplega@iupui.edu). Ms. received 9/06; accepted 1/07; revised 1/07.

\section{IV: Students}

The school applies the results of evaluation of student achievement to program development. Procedures are established for systematic evaluation of the degree to which a program's academic and administrative policies and activities regarding students are achieving its objectives. ${ }^{3}$

Because the standards specify the importance of evaluation and evaluative data, this article examines program presentations prepared for ALA accreditation - the primary documentation of how the standards are met-to review in what way library and information science (LIS) masters programs report that student learning outcomes are assessed and their evaluation utilized in program planning.

\section{Background}

Professional accreditation is part of overall academic evaluation. The public's view of institutional evaluation has largely revolved around input and process variables. For the 2006 U.S. News and World Report college rankings, the largest single factor (25\%) was a reputational survey. Input data (quality of students, faculty characteristics, and spending per student) made up approximately $35 \%$; process variables such as class size approximately $10 \%$; and a type of indirect outcomes data-graduation and retention rates-the remainder. ${ }^{4}$ The National Survey of Student Engagement, something of a competitor in terms of institutional assessment, is primarily process-oriented, asking students what kinds of educational experiences they have engaged in at their institution. ${ }^{5}$

There have been relatively few attempts to rate or rank library schools. The U.S. News graduate school rankings for library science and the White studies use only reputational surveys. ${ }^{6}$ Other researchers have studied faculty (e.g. publications ${ }^{7}$ and general qualifications ${ }^{8}$ ); student or alumni feedback ${ }^{9}$ and employer feedback. ${ }^{10}$ Some review administrative inputs such as faculty-student ratio or budgets. ${ }^{\prime \prime}$

To a large degree dissatisfaction with these reputational, input and process oriented approaches contributed to the growing development of an outcomes-based approach, strengthening in the 1980s and 1990s. All of the regional institution-accrediting organizations incorporated explicit language and strong emphases upon the assessment of student learning as they updated their standards.

Library science and other professional and specialized programs, (such 
as nursing, engineering, business, social work, etc.), were influenced by this movement from two directions. First, as demonstrated by the 1992 ALA criteria, their accreditors adopted outcomes language; second, as programs housed in institutions accredited by five regional accreditors, LIS programs have found those colleges and universities requesting outcomes information as part of institutional accreditation, program review, and continuous improvement processes. ${ }^{12}$ The Council on Regional Accrediting Commissions states clearly:

II. What an accrediting commission should reasonably expect of itself:

1. The centrality of student learning in accreditation. Evaluation of an institution's success in achieving student learning is central to each commission's function and public charter. The review of student learning is conducted within the context of the mission of the institution and is based on the suitability and effectiveness of processes designed to accomplish institutional goals and on the institution's continued ability to fulfill its purposes.

2. Evidence of student learning for accreditation. Commissions focus on the strength of the institution's claim that it is fulfilling its declared educational mission and give particular attention to how the institution's collection and use of student learning evidence helps to achieve its learning goals. ${ }^{13}$

\section{Scope}

Given this growing importance of evaluation in accreditation criteria, this study focuses on the specific arena of student learning outcomes measurement within LIS programs. It begins with an overview of approaches to learning outcomes measurement. It then reviews "program presentations," documents prepared by LIS masters programs for ALA accreditation, to examine how programs discuss, analyze, and display their learning outcomes assessment procedures and data.

The raw data for the review is comprised of fifteen program presentations. These were selected as the most valid though not the most thorough evidence of the processes at some LIS programs. There are few alternatives, chiefly because evaluation of students and programs is largely an internal process.

Very little has been published in the journal literature about LIS program assessment with respect to learning outcomes. In 1995 and 1996, Watson-Boone and Weingand's studies of sixty-nine "indicators of effectiveness" for library school programs included overwhelmingly input (e.g. "faculty awareness of new developments in the field") and administrative (e.g. "use of adjunct faculty, guest lecturers") items. ${ }^{14}$ Five could be characterized as learning outcomes: ability of graduates to handle change, competency of students in core courses, extent graduates are fully trained for first professional job, extent graduates think beyond immediate job to larger issues, and orientation of grads re problem solving/decision making. Only one-“fully trained"- was deemed "essential" by as many as three of the four respondent groups: administrators, alumni, and employees. The low 
ratings for "core course" achievement-rated "low" by administrators and alumni-supports the argument made by many in the assessment field that course grades alone are an indirect, at best, measure of student learning.

In 2002, Perrault, Gregory and Carey described pilot discussions about conceptualizing and measuring student learning outcomes at the University of South Florida. USF SLIS was one of nine campus departments or programs involved in this effort, which shows the importance of institutional demands ${ }^{15}$; a fuller description has not (yet) been published. In 2001, Pors reported on a review of mandatory exam results from Danish library schools, but his goal was an investigation of the relationship between exams and student evaluations of faculty. ${ }^{16}$

A less-formal venue than journal publication has also seen relatively little appearance of learning outcomes assessment. Presentations at the Association of Library and Information Science Education annual conferences in the 2001-2004 period have included several on core competencies, and on various specific subject areas (e.g. digital librarianship, research methods), but very few where the presentation title or description indicates a focus on evaluation of student learning; a 2001 presentation by James Carey appeared to include the only direct reference: the abstract for "Implications of Learner-Centered Pedagogy for programmatic Efficiency and Accountability in Library and Information Science Education" includes: "suggests a model for managing programmatic requirements for efficiency and regional/professional accountability."17

Because the COA standards specify the importance of outcomes assessment, the presumption here is that a program presentation would include any relevant data that exists. The strength of this approach is that a program presentation is a non-reactive methodology: the data exists before being examined. Survey responses, in contrast, may be influenced by respondents' desire to represent their programs in one way or another. A program presentation is created specifically and explicitly for the sake of examining thoroughly and accurately a particular masters program, and is subject to external review (by COA site visitors).

The major weakness of this approach is that the fifteen program presentations which were publicly available do not represent the universe of, or a validly random sample of, library schools. A program presentation is the property of the school creating it, and it is the school's decision to make it public. The other weakness is that programs may indeed incorporate evaluation into their processes, without documenting it in the program presentations. Just as faculty members who do not use explicit "rubrics" nevertheless still have their own internal criteria for grading, a program that does not specify its evaluation processes may still incorporate an evaluative attitude into its decision-making. It is assumed that this latter problem is relatively minor, however. Since COA has made assessment clearly important, programs with excellent evaluative systems should be proud to document them in their program presentations. 


\section{Review: Categorization of Student Learning Outcome Assessment}

Within the higher education assessment community, there is a reasonable amount of consensus on the usefulness of various tools to assess student learning outcomes. Measures are characterized as direct, indirect, and non-measures of student learning: these, respectively, explore what has been learned, that learning has (probably) occurred, and other items perhaps informative but not indicative of learning. ${ }^{18}$

Direct measures are those which provide evidence of what exactly has been learned, and how well; they require students to demonstrate knowledge or skills. Common direct measures include tests, projects, and performances evaluated by experts.

Indirect measures are more informative about the fact that learning has occurred, or how it has occurred. Indirect measures include those which require students to reflect upon their learning (such as their attitude towards the process, or their own assessment of skills, etc. ${ }^{19}$ ) as seen in surveys and self-reports. They can provide additional knowledge and perspectives, such as from alumni or employers. ${ }^{20}$ Finally, they may simply indicate that (presumably) learning has occurred: data such as placement rates and prizes won. ${ }^{21}$

LIS program administrators and faculty would want to know a host of additional data points which are very useful for administration and design, but are not informative about student learning ("non-measures"). These include faculty-student ratios, course selection patterns, curricular mapping, and evaluation of advising.

For most assessors, but to the surprise of faculty in many fields, course grades and overall grade point averages usually are also considered "non-measures." The main reason for this is that even a single-assignment grade can be a "mixed" measure. That is, it may include content mastery, grammatical correctness, and timeliness (or not) of completing the assignment. Unless these individual elements are preserved, the overall grade become a very "fuzzy" measure of learning -and course grades and GPAs fuzzier still.

\section{LIS Student Learning Assessment: Program Presentations}

For this study, fifteen program presentations were examined; the list is given in Appendix A. The dates of the presentations are important, as programs may have seen more parent-institutional emphasis on student learning assessment in more recent years. Each presentation's sections on curriculum (II) and on students (IV) were examined for the tools reported as being used to derive student learning outcomes information. While some programs chose a more narrative or more integrated approach to specific 
standard elements, it is in these sections that any existing data sources should have been at least mentioned.

In the results described below, institutions are not individually identified. A letter from $\mathrm{A}$ to $\mathrm{H}$ was assigned to program presentations completed in 2002 to 2005 ; from W to $\mathrm{Z}$ to presentations completed from 1998 to 2001. The purpose of this research is to show some practices of library programs, not to single out individual institutions as users of direct, indirect, or non-measures.

Table 1 shows the most common evaluative tools: tools used by more than half of the institutions included. Even the most common measures were used by only 9 of 15 schools $(60 \%)$; some schools used all five measures; others only two or three. Table 2 provides examples of the wording used by program presentations about these tools.

As the samples show, there were slight variations in how program presentations named or described these tools. A content analysis grouped and defined these in this way for this study:

- Student surveys were administered to currently enrolled students, outside of class.

- Course evaluations were end-of-course evaluations. It was often not possible to determine if they contained indirect measures such as student perceptions of their own mastery, or of the relevance of the content, or only non-measures such as items asking about faculty competence or practices.

Table 1

Most Common Measures Used.

\begin{tabular}{|c|c|c|c|c|c|}
\hline LIS program & $\begin{array}{l}\text { Student } \\
\text { Surveys }\end{array}$ & $\begin{array}{c}\text { Student } \\
\text { Course } \\
\text { Evaluations }\end{array}$ & $\begin{array}{l}\text { Alumni } \\
\text { Surveys }\end{array}$ & $\begin{array}{l}\text { Employer } \\
\text { Surveys }\end{array}$ & $\begin{array}{l}\text { Exit } \\
\text { Survey }\end{array}$ \\
\hline $\bar{A}$ & $\bar{x}$ & & $\bar{x}$ & & \\
\hline B & $x$ & $x$ & $x$ & $x$ & $x$ \\
\hline C & $x$ & & & & $x$ \\
\hline $\mathrm{D}$ & $x$ & $x$ & & & $x$ \\
\hline$E$ & & & $x$ & $x$ & $x$ \\
\hline $\mathrm{F}$ & & $x$ & $x$ & & \\
\hline$G$ & & $x$ & $x$ & $x$ & \\
\hline \multicolumn{6}{|l|}{$H$} \\
\hline 1 & $x$ & $x$ & & $x$ & $x$ \\
\hline$U$ & $x$ & $x$ & $x$ & $x$ & \\
\hline V & $x$ & $x$ & & & \\
\hline W & & $x$ & $x$ & $x$ & $x$ \\
\hline$x$ & $x$ & & $x$ & $x$ & \\
\hline Y & $x$ & $x$ & $x$ & & $x$ \\
\hline Z & & & & $x$ & $x$ \\
\hline Total using: & 9 & 9 & 9 & 8 & 8 \\
\hline
\end{tabular}


Table 2

Program Presentation Wording, Common Measures.

\begin{tabular}{ll}
\hline Course evaluations & "Student evaluations are used on an ongoing basis as \\
part of the evaluation process." & "The course evaluation forms and a statistical summary \\
are reviewed by the Director ..." & "Current student and graduate surveys." \\
"In addition, the program conducts regular surveys of & students ..." \\
Student surveys & "An exit survey of students graduating in X asked to what \\
extent the program has prepared the student to be a \\
leader/change agent in the information professions." \\
"Recent graduates are surveyed annually . . rated their \\
courses as good or excellent." \\
"A survey of alumni from 19xx-2xxx, asking questions \\
about practical experiences." \\
"Regular surveys of alumni" \\
"Ischool] will continue to use a number of assessment \\
tools, such as surveys of ... employers." \\
"Surveys of employers of the program's graduates."
\end{tabular}

- Alumni surveys were administered usually to all contact-able alumni, regardless of the year of graduation (distinguished from "exit surveys").

- Employer surveys may have included indirect and non-measures; in contrast to internship supervisor evaluations, there was no indication that employers were advised, trained, or expected to provide direct consistent performance evaluations but were generally commenting on graduates' preparedness.

- An exit survey was administered at or closely following graduation; it was sent to one year's (term's) group of graduates, in contrast to the more broadly defined "alumni" group.

There were other tools that were mentioned by fewer institutions:

- 6 institutions: job placements (in detail, or by rates)

- 4 institutions: class assignments, activities or exams, as observed or reviewed by person(s) other than the course instructor.

- 4 institutions: student forums, here including all informal methods including vaguely worded "feedback," "input" from advising sessions, list-servs and email, as well as open sessions inviting feedback.

- 3 institutions: student focus groups or interviews.

- 2 institutions: a capstone/portfolio document.

- 2 institutions: internship supervisor evaluations. 


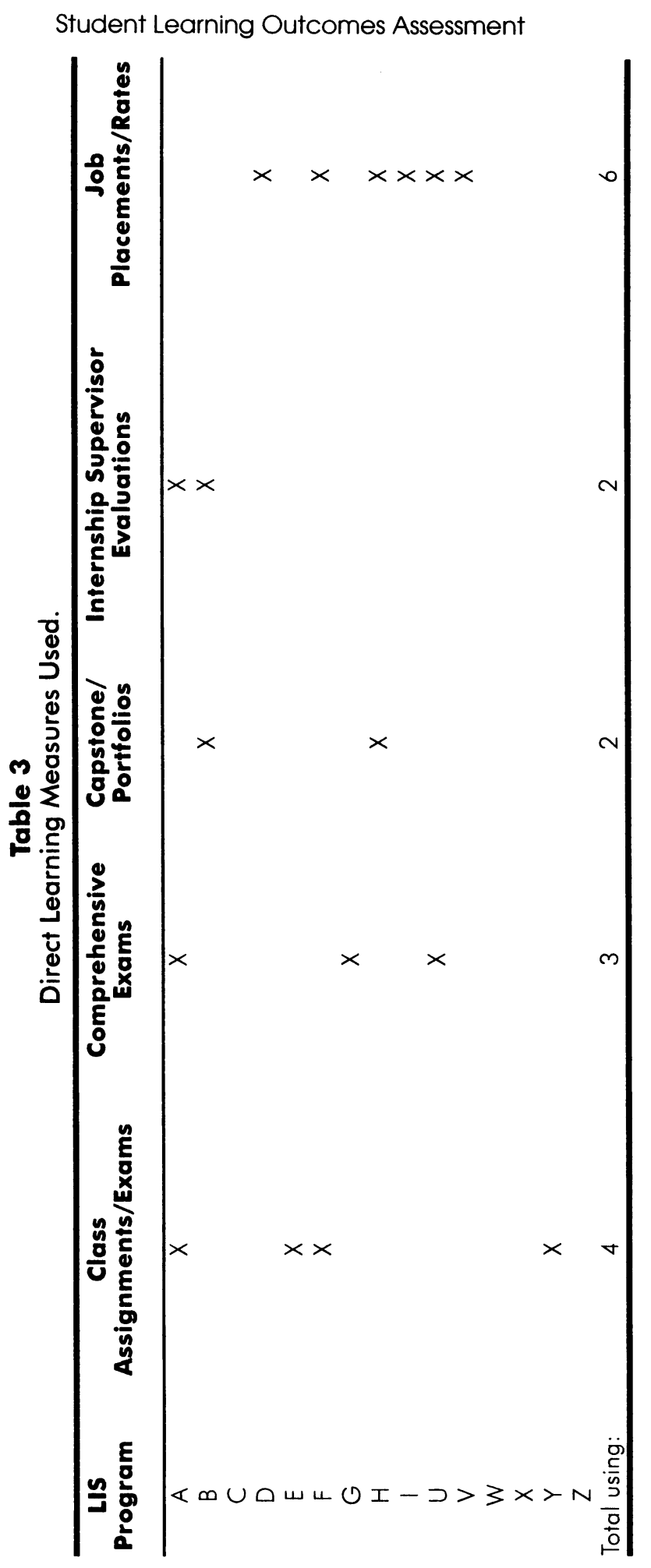




\section{Table 4}

Program Presentation Wording, Direct Measures.

Class assignments/exams "Students receive systematic, multifaceted evaluation of
their achievements. Assessment varies in keeping with
the subject matter of the course."
"Student achievement is assessed in each course on the
basis of in-class and out-of-class
assignments/activities."
"At the program level, comprehensive examination
results have long provided a barometer of
achievement."
"student performance on the final examination...
indicate[s] a positive, and high, level of academic
achievement."
"Students develop a portfolio that must include their
reflections and assessments of the program, as well as
demonstrate the knowledge, skills, and professional
values learned during the MLS program...Portfolios are
evaluated..."
"Evaluation of the final portfolio the student submits as
the capstone project at the end of the program."
"An analysis of xxx student and mentor evaluations for
experiences"
"For school media students, the practicum is a major
gauge of student achievements."
"Job placement for graduates"
Internship supervisor

In contrast with the most common, Table 3 highlights the most direct learning outcomes indicators, and the institutions using them; Table 4 gives examples of wording.

These tables include job placements although most observers of assessment would classify that as an indirect measure: that is, it usually will indicate that learning has occurred, but it gives no detailed information about what learning occurred. It is, however, popular among programs and also of interest to students: arguably it is the most important outcome for those investing time and money in their education.

The Curriculum and Student sections also contain many sources of information that are not measures of student learning. These are often described in detail, and have obviously useful applications to the intelligent design and delivery of library school curricula. Examples include:

- comparing curricular content to job descriptions or interviews with employers; examining course syllabi and reading lists.

- surveying faculty as to the coverage of core requirements in their courses.

- monitoring student retention rates, course selection and specialization choices. 
Table 5

Program Presentations and ALA Evidence Examples.

\begin{tabular}{lc}
\hline Examples of Evidence & $\begin{array}{c}\text { Number of } \\
\text { Presentations }\end{array}$ \\
\hline $\begin{array}{l}\text { Summaries and examples of student portfolios or results of } \\
\text { capstone experiences }\end{array}$ & 2 \\
$\begin{array}{l}\text { Student and/or employer assessment of internship or practicum } \\
\text { experiences }\end{array}$ & 2 \\
$\begin{array}{l}\text { Evidence of the rate and types of employment of program } \\
\text { graduates }\end{array}$ & 6 \\
$\begin{array}{l}\text { Results of student follow-up surveys regarding the effectiveness } \\
\text { of the educational experiences }\end{array}$ & 9 \\
\hline
\end{tabular}

- matching entrance requirements such as undergraduate GPAs to subsequent student performance (program GPAs).

The ALA Accreditation Process, Policies and Procedures handbook provides a table listing examples of the "evidence for meeting the standards for accreditation." 22 Some of these specifically pertain to learning outcomes assessment. Table 5 compares these examples of evidence with the numbers of program presentations examined which include them.

Overall, most of the measures included in program presentations give indirect evidence, at best, about student attainment of learning objectives. The most common tool, a survey of some sort, is highly dependent upon self-awareness and self-assessment.

On the positive side, programs seem widely interested in constituent perspectives. Thirteen of fifteen programs use some form of input by or from employers: job placement rates, or employer surveys or interviews. Thirteen of fifteen also mentioned input from students beyond course evaluations: interviews, surveys, forums and other methods.

Direct, specific measures of exact learning are less common. In this group of presentations, only eight of the fifteen employed at least one direct measure $(53 \%)$.

\section{Discussion}

In considering evaluation, LIS programs are faced with competing pressures and concerns. Put simply, evaluation costs time and effort; it promises better data for program improvement.

It appears likely that institutional accreditors will continue and even increase their emphasis on accountability, defined at least partially as measurement of student learning. Some states may see increased legislative attention to the "usefulness" of publicly supported universities. On the 
other hand, it is also possible that in large institutions, administrators may focus more on undergraduate goals. Graduate programs such as LIS could escape much institutional notice.

An overall assessment plan takes time and energy. Even surveys take resources to design, administer-and attempt to achieve a respectable return rate. Many program presentations were blunt about the difficulty of surveying alumni and employers.

Assessing specific learning outcomes is even more complex, demanding nothing less than faculty expertise, and time. Depending on how it is structured, it may also pose an added burden upon students, such as with comprehensive exams and theses, options used by under half of all American LIS programs. ${ }^{23}$ Another possibility is a portfolio approach. A portfolio can be a container for documents or records of student achievements. From the student perspective, a portfolio may serve as a "super-resume," demonstrating, not just listing, relevant skills. From a program perspective, portfolios can be organized around learning outcomes. Faculty evaluators then examine materials pertaining to each defined outcome, and derive from them a rich understanding of how well each outcome is being mastered by their student body as a whole-and where problems may exist.

The philosophy driving the assessment movement is that the complete assessment cycle-articulation of outcomes, measurement, and changes in programs based on that data-will result in improved student learning. This overall goal has yet to be widely researched and confirmed on a program level-however useful small-scale content or learner-specific research has proven in showing "what works." In the summer of 2006 a major study by the accrediting body for engineering education, ABET, did find that changed accreditation requirements made a difference to their profession's educational process and student outcomes: the study showed major changes in curriculum, student experiences, and faculty practices due to assessment procedures, and found a statistically significant increase in an indirect measure of student learning: student self-report of skills. ${ }^{24}$

The library field, along with other academic disciplines, cannot yet claim such data. However, at the least, an increased emphasis on the direct measurement of student learning could potentially provide richer data for:

- internal program analysis and improvement

- educational and professional accountability to parent institutions, regional accreditors, $\mathrm{COA}$, and practitioners

- prospective and graduating students, to illustrate or demonstrate their value to employers

Since the present research was confined to program presentations at one point in time, further research and sharing of evaluative processes and information would benefit LIS programs and the profession as a whole. 


\section{Appendix: Institution program Presentations}

\begin{tabular}{lc}
\hline Institution & Year of Presentation \\
\hline Emporia & 2005 \\
U. of Missouri-Columbia & 2004 \\
Indiana U. & 2004 \\
St. Johns U. & 2004 \\
U. Illinois Urbana Champaign & 2004 \\
U. Kentucky & 2004 \\
UNC-Greensboro & 2004 \\
U. Michigan & 2003 \\
Clarion U. & 2003 \\
Wayne State U. & 2002 \\
U. Rhode Island & 2000 \\
UNC-Chapel Hill & 1999 \\
U. Alberta & 1999 \\
U. Washington & 1998 \\
U. Hawaii & 1998 \\
\hline
\end{tabular}

\section{References}

1. Robert C. Dickeson, The Need for Accreditation Reform: An Issue Paper for a National Dialogue: The Secretary of Education's Commission on the Future of Higher Education. Washington, DC: U.S. Department of Education, 2006, http://www.ed.gov/about/ bdscomm/list/hiedfuture/reports/dickeson.pdf (accessed June 22, 2006.)

2. American Library Association, Standards for Accreditation of Master's programs in Library and Information Studies, 1992, http://www.ala.org/ala/accreditation/ accredstandards/Standards.rtf. (accessed Feb. 6, 2006).

3. Ibid.

4. U.S. News and World Report, "Undergraduate Ranking Criteria and Weights," http://www.usnews.com/usnews/edu/college/rankings/about/weight_brief.php (accessed 7 June 2006).

5. National Survey of Student Engagement, 2006, http://.nsse.iub.edu/ (accessed July 7, 2006).

6. U.S. News and World Report, "Library and Information Studies Methodology," 2005, http://www.usnews.com/usnews/edu/grad/rankings/about/07lib_meth_brief.php. (accessed July 7, 2006, 2006); Herbert S. White, "Perceptions by Educators and Administrators of the Ranking of Library School programs: The Third in a Series of Studies Undertaken in Six-Year Intervals," Library Quarterly 63, no. 2 (1993): 166-88.

7. Marcia J. Bates, "The Role of Publication Type in the Evaluation of LIS programs," Library and Information Science Research 20, no. 2 (1998): 187-98.

$\rightarrow$ Barbara Moran, "Evaluation of Faculty in Schools of Library and Information Science: An Element in Educational Excellence," Journal of Education for Library and Information Science 32, no. 3-4 (1991): 207-15.

9. Barbara A. Frey, Susan Webreck Alman, Dan Barron, and Anne Steffens, "Student Satisfaction with the Online MLIS program at the University of Pittsburgh," Journal of Education for Library and Information Science 45, no. 2 (2004): 82-97; a part of Wu Guang-Wei, "Management and Qualitative and Quantitative Evaluation of Library School Teachers in China," Education for Information 7, no. 1 (1989): 3-16; and Eloise May, "What Students Are Saying About Library Education," Colorado Libraries 29, no. 2 (2003): 13-14. 
10. Dianne Oberg and Eunice Easton, "Focus Group Interviews: A Tool for program Evaluation in School Library Education," Education for Information 13 (1995): 117-29.

11. Bob Molyneux, "Devil's Advocate: Canaries in the Coal Mine," Against the Grain (2001): 38-39; Edna Blackie, "On Designing an Honours Degree in Information and Library Studies," Training and Education 5, no. 3 (1988): 57-63; John Philip Mulvaney, "The Characteristics Associated with Perceived Quality in Schools of Library and Information Science," Library Quarterly 62, no. 1 (1992): 1-27, and John Philip Mulvaney, “The Characteristics Associated with Perceived Quality in Schools of Library and Information Science: An Update and Prediction." Library Quarterly 63, no. 2 (1993): 189-91.

12. Peter Hernon, and Robert E. Dugan, Outcomes Assessment in Higher Education: Views and Perspectives. Westport, Conn.: Libraries Unlimited, 2004.

13. Council of Regional Accrediting Commissions, Regional Accreditation and Student Learning: Principles for Good Practices, http://www.ncahigherlearningcommission.org/ download/0412Assessment AccredLearningPrinciples.PDF. (accessed Feb. 6, 2006, 2006).

14. Rebecca Watson-Boone and Darlene Weingand, "Profiles of Constituent Groups: Indicators of Effectiveness of Schools of Library and Information Studies," Journal of Education for Library and Information Science 36, no. 2 (1995): 104-25; Rebecca Watson-Boone and Darlene Weingand, "Deans Rank Indicators of Effectiveness for Schools of Library and Information Studies," Journal of Education for Library and Information Science 37, no. 1 (1996): 30-43.

15. Anna H. Perrault, Vicki L. Gregory, and James O. Carey. "The Integration of Assessment of Student Learning Outcomes with Teaching Effectiveness," Journal of Education for Library and Information Science 43, no. 4 (2002): 270-80.

16. Niels Ole Pors, "Measuring Students' Performance and Perceptions: Empirical Studies in Different Dimensions of Quality Assurance at a Library School," New Library World 102, no. 1170-1171 (2001): 429-35.

17. Association of Library and Information Science Education, "Past Events," http://www.alise.org/conferences/past.html (accessed February 6, 2006).

18. The three major texts on evaluation in higher education are: Catherine A. Palomba and Trudy W. Banta, Assessment Essentials: Planning, Implementing, and Improving Assessment in Higher Education. San Francisco: Jossey-Bass, 1999; Cecilia Lopez, "Opportunities for Improvement: Advice from Consultant-Evaluators on programs to Assess Student Learning," [Chicago]: North Central Accreditation Commission on Institutions of Higher Education [now: the Higher Learning Commission], 1997, http://www.ncahlc.org/download/97ASSESS.pdf; and Linda Suskie, Assessing Student Learning: A Common Sense Guide. Bolton, Mass.: Anker, 2004. These three sources agree mainly on the definitions of "direct" and "non-measures" as described further; they differ slightly in categorizing "indirect" measures.

19. This is the interpretation used by Palomba and Banta, Assessment Essentials.

20. This is the main interpretation used by Lopez, "Opportunities for Improvement."

21. This is the main interpretation used by Suskie, Assessing Student Learning.

22. American Library Association, Committee on Accreditation, Accreditation Process Policies and Procedures, effective February 1, 2003, Chicago: American Library Association Office for Accreditation, 2003, 31.

23. The author's research assistant, Anne Marie Moser, in 2005 checked the Web sites of United States ALA-accredited library schools and counted those requiring either comprehensive exams or theses.

24. Lisa Lattuca, Patrick T. Terenzini, and J. Fredricks Volkwein, Engineering Change: A Study of the Effect of Ec2000: Executive Summary, 2006. http://www.abet.org/ Linked\%20Documents-UPDATE/White\%20Papers/Engineering\%20Change.pdf. (accessed 7 June 2006, 2006). 